\title{
INVENTARISASI POTENSI KAWASAN KARST PAMEKASAN, MADURA UTARA
}

\author{
Widya Utama, Krishna Wijaya, Raden Aldi, Hasibatul Farida R, Budi, Suto \\ Jurusan Teknik Geofisika, FTSP Institut Teknologi Sepuluh Nopember \\ e-mail: widya@geofisika.its.ac.id
}

\begin{abstract}
Abstrak. Kawasan karst memiliki peran penting dalam ekosistem, seperti menyediakan air bersih, material alam berbasis kapur, dan pengendali perubahan iklim. Meskipun sangat berperan dalam ekosistem, kawasan karst rentan terhadap gangguan dinamika sosial ekonomi masyarakat yang tidak terarah. Salah satu kawasan karst yang terancam keberadaannya adalah di Kabupaten Pamekasan akibat adanya kegiatan pertambangan di kawasan tersebut. Oleh karena itu perlu dilakukan penelitian di kawasan karst guna mendukung penyusunan kebijakan mengenai perlindungan dan pemanfaatan kawasan karst. Penelitian ini bermaksud memetakan potensi kawasan karst dan membuat zonasi kawasan yang mengarah kepada pemanfaatan ekonomi namun mendukung upaya pelestarian kawasan karst di wilayah Pamekasan Utara. Penelitian ini dilakukan dengan pengambilan data sekunder dan primer, pembuatan data base, analisis data, dan pembuatan peta zonasi dan potensi kawasan karst. Hasil survei menunjukkan bahwa kawasan karst berada di daerah sekitar Antiklin Tempajung dan Sinklin Eden di atas formasi Tmtn (Formasi Ngrayong). Karst yang ditemukan memiliki morfologi yang beraneka ragam, misalnya kerucut karst (lokasi: Tengah Kabupaten Pamekasan), gua (lokasi: Gunung Waru, Bongagung, dan Paseset), dan sungai bawah tanah. Selain itu, kawasan karst juga memiliki banyak potensi, di antaranya flora, fauna, sumber daya air, dan pariwisata. Melihat potensi kawasan karst maka akan lebih bermanfaat jika kawasan karst dilestarikan dari pada dijadikan daerah tambang. Berdasarkan penelitian yang telah dilakukan, maka dapat disimpulkan bahwa kawasan karst di Pamekasan Utara tergolong ke dalam merokarst, potensi kawasan karst di wilayah tersebut terbagi menjadi dua yaitu potensi sebagai sumber daya alam dan potensi pariwisata, serta penataan ruang kawasan karst dikelompokkan menjadi kawasan lindung dan kawasan budidaya.
\end{abstract}

Kata kunci: karst; Pamekasan; Madura Utara; sungai bawah tanah; penataan ruang

\begin{abstract}
Karst area has an important role in ecosystem, as supply clean water, lime based natural materials, and climate changing controller. Although it plays an imporrtant role in ecosystem, karst area is susceptible to undirected society social-economics dynamics disturbance. One of endangered karst area is lied in district of Pamekasan as consequence of mining activity in that area. Therefore, it's need a research in karst area for support policy making about protection and utilization karst area. This research intends to map out karst area potential and creat zoning area that led to the economics use but support karst area conservation in North Pamekasan. This research was conducted by collecting secondary and primary data, data base making, data analysis, and zoning and potential karst area making. The result of this research indicates that karst area lies on around Tempajung anticline and Eden syncline above Tmtn formation (Ngrayong Formation). Found karst area has variety morphology, as cone karst (location: middle of Pamekasan district), cave (location: Waru, Bongagung, and Paseset Mount), and underground river. Besides the karst area also has so many potential, as flora, fauna, water resource, and tourism. Seeing this karst area potential will be more useful if karst area is used as conservation area than mining area. Based on this research conducted it can be concluded that karst area in North Pamekasan includes merokarst, karst area potential in that area is divided into two: natural resources and tourism potential, and spatial planning of karst area grouped into protected area and cultivation area.
\end{abstract}

Keywords: karst; Pamekasan; North Madur, underground river; spatial planning

\section{PENDAHULUAN}

Peraturan Menteri Energi dan Sumber Daya Mineral (Permen ESDM) Nomor 17 Tahun 2012 Pasal 3 menyebutkan bahwa "kawasan bentang alam karst merupakan kawasan lindung geologi sebagai bagian dari kawasan lindung nasional".
Masih menurut Permen ESDM Nomor 17 Tahun 2012 tersebut, pada Pasal 4 ayat (1) menyebutkan bahwa "Kawasan bentang alam karst sebagaimana dimaksud dalam Pasal 3 merupakan kawasan bentang alam karst yang menunjukkan bentuk eksokarst dan endokarst". Bentuk eksokarst yang 
disebutkan dalam Permen ESDM Nomor 17 Tahun 2012 Pasal 4 ayat (5) terdiri atas: mata air permanen, bukit karst, dolina, uvala, polje, dan/atau telaga. Sedangkan Pasal 4 ayat (6) menyebutkan bahwa "bentuk endokarst terdiri atas sungai bawah tanah dan/atau speleotem".

Bentang lahan karst menyediakan jasa ekosistem seperti air bersih, bahan-bahan material, dan menjadi agen pengendali perubahan iklim (Brinkmann dan Jo Garren, 2011). Di samping sumber daya air, kawasan karst memiliki berbagai sumber daya yang sangat potensial untuk dikembangkan seperti sumber daya lahan, sumber daya hayati, dan potensi bentang lahan baik permukaan atau pun bawah permukaan (Suryatmojo, 2006). Oleh karena itu kawasan karst perlu dijaga kelestarianya. Walaupun wilayah karst berperan penting dalam ekosistem, tetapi kawasan karst rentan terhadap gangguan dinamika sosial ekonomi masyarakat yang tidak terarah, sehingga dibutuhkan kebijakan perlindungan dan pemanfaatan kawasan secara berkelanjutan.

Sesuai dengan amanat Permen ESDM Nomor 17 Tahun 2012 bahwa bentang alam karst merupakan bentang alam yang menunjukkan bentuk eksokarst dan endokarst merupakan kawasan karst, maka beberapa kawasan batu gamping di Kabupaten Pamekasan merupakan kawasan karst yang perlu dilestarikan. Keindahan karst di Kabupaten Pamekasan tersebut saat ini mulai terancam keberadaannya dengan adanya kegiatan pertambangan batu gamping di kawasan karst, antara lain di Desa Blaban Kecamatan Batumarmar. Guna mendukung penyusunan kebijakan mengenai perlindungan dan pemanfaatan kawasan karst maka diperlukan penelitian di kawasan karst.

Penelitian di kawasan karst meliputi pemetaan kawasan yang digunakan sebagai data dasar bagi pengembangan kawasan karst berbasis lingkungan lestari. Kemudian perencanaan dan penataan tata ruang yang matang terarah dan terpadu pada kawasan karst yang menjadi pedoman umum bagi pengembangan potensi sosial ekonomi masyarakat di sekitar kawasan. Dimana pada akhirnya diperlukan penentuan sarana prasarana pendukung untuk memanfaatkan kawasan karst yang berbasis kelestarian lingkungan.

Penelitian ini dilakukan di daerah Pamekasan. Kabupaten Pamekasan adalah sebuah kabupaten di Pulau Madura, Provinsi Jawa Timur, Indonesia dengan posisi geografis antara 6051' - 7o13' LS dan 113019'-113058' BT. Ditinjau dari topografinya, wilayah Kabupaten Pamekasan terdiri dari tiga macam wilayah yaitu, wilayah datar atau rata, bergelombang atau perbukitan, dan daerah pantai. Kabupaten Pamekasan bagian utara ini terdiri dari lima formasi, antara lain:

\section{Formasi Tawun}

Formasi ini memiliki sedikit persamaan dengan formasi yang berada di Kecamatan Pakong. Terdapat tiga gradasi yang terdiri dari batu lempung gampingan di bagian bawah, napal pasiran dengan sisipan batu gamping di tengah, dan batu pasir gampingan di bagian atas.

2. Formasi Ngrayong

Formasi ini memliki perselingan atara batu pasir dan batu lempung pasiran serta adanya sisipan batu lempung dan batu gamping.

3. Formasi Bulu

Formasi ini memiliki kesamaan dengan Formasi Tawun akan tetapi pada formasi ini terdapat kalkarenit.

4. Formasi Madura

Formasi ini terdapat di daerah dataran rendah, atau mendominasi daerah yang menuju ke pantai utara Kabupaten Pamekasan. Dengan lapisan bawah adalah batu gamping kapuan dan bagian atas batu gamping terumbu.

5. Aluvial

Formasi ini mendominasi daerah pantai pesisir utara Kabupaten Pamekasan Utara. Pada daerah ini didominasi hasil endapan sepanjang pantai, lempung, kerakal, krikil, pasir, dan karbonat sebagai pembentuk endapan tersebut.

Kabupaten Pamekasan memiliki jumlah penduduk sebanyak 795.801 jiwa, yang terdiri dari jumlah penduduk laki-laki sebesar 393.306 jiwa, dan penduduk perempuan sebanyak 402.495 jiwa dengan kepadatan wilyah sebesar 1004 jiwa/km2 (data Pamekasan dalam angka tahun 2007). Agama mayoritas penduduk Pamekasan adalah islam, dan 
tingkat pendidikannya beragam. Menurut dinas pendidikan Kabupaten Pamekasan, tingkat pendidikan masyarakat Pamekasan, terutama yang tinggal di daearah pedesaan masih relatif rendah, hal ini dipengaruhi oleh adanya pandangan terhadap bahwa pendidikan tidak menjamin seseorang menjadi sukses dan kaya. Sedangkan pertumbuhan ekonomi Kabupaten Pamekasan, sangat dipengaruhi oleh tiga sektor utama, yaitu pertanian, jasa, dan perdagangan. Misalnya pada tahun 2001 pertumbuhan ekonominya mencapai $1,59 \%$ yang disumbangkan oleh sektor pertanian $(52,48 \%)$, jasa $(19,147 \%)$, dan perdagangan $(9,35$ $\%)$.

Penelitian ini bermaksud untuk memetakan potensi kawasan karst dan membuat zonasi kawasan yang mengarah kepada pemanfaatan ekonomi namun mendukung upaya pelestarian kawasan karst. Adapun tujuan dari penelitian ini di antaranya adalah melakukan zonasi kawasan karst pada formasi Pamekasan Utara, melakukan pemetaan potensi kawasan karst yang dapat memberi nilai tambah ekonomi pada masyarakat setempat, serta memberikan rekomendasi terhadap arahan kebijakan pengembangan sosial ekonomi masyarakat di sekitar kawasan karst yang berbasis kelestarian lingkungan.

\section{Definisi dan Klasifikasi Karst}

Ford dan Williams (1989) mendefinisikan karst sebagai medan dengan kondisi hidrologi yang khas sebagai akibat dari batuan yang mudah larut dan mempunyai porositas sekunder yang berkembang baik. Ciri-ciri karst yaitu terdapatnya cekungan tertutup dan/atau lembah kering dalam berbagai ukuran dan bentuk, langka atau tidak terdapat drainase atau sungai permukaan, dan terdapat gua dari sistem drainase bawah tanah.

Karstifikasi atau proses permbentukan bentuk lahan karst didominasi oleh proses pelarutan. Proses pelarutan batu gamping diawali oleh larutnya $\mathrm{CO} 2$ di dalam air membentuk $\mathrm{H} 2 \mathrm{CO} 3$. Larutan $\mathrm{H} 2 \mathrm{CO} 3$ tidak stabil terurai menjadi $\mathrm{H}$ - dan $\mathrm{HCO} 32-$. Ion $\mathrm{H}$ - inilah yang selanjutnya menguraikan $\mathrm{CaCO} 3$ menjadi $\mathrm{Ca} 2+$ dan HCO32-. Secara ringkas proses pelarutan dirumuskan dengan reaksi sebagai berikut.

$$
\mathrm{CaCO}_{3}+\mathrm{H}_{2} \mathrm{O}+\mathrm{CO}_{2} \mathrm{Ca}^{2+}+2 \mathrm{HCO}_{3}{ }^{2-}
$$

Topografi karst telah banyak ditemukan di berbagai tempat di belahan bumi dengan berbagai tipe. Peneliti karst telah mencoba menjelaskan variasi karst dan mengklasifikasi tipe-tipe karst. Berikut adalah beberapa klasifikasi tersebut.

1. Klasifikasi Cvijic (1914)

Klasifikasi ini didasarkan pada perkembangan dan dibagi menjadi tiga yaitu holokarst, merokarst, dan karst transisi.

- Holokarst merupakan karst dengan perkembangan paling sempurna, baik dari sudut pandang bentuk lahannya maupun hidrologi bawah permukaannya. Karst tipe ini dapat terjadi bila perkembangan karst secara horizontal dan vertikal tidak terbatas, batuan karbonat masif dan murni dengan kekar vertikal yang menerus dari permukaan hingga batuan dasarnya, serta tidak terdapat batuan impermeable yang berarti.

- Merokarst merupakan karst dengan perkembangan tidak sempurna atau parsial dengan hanya mempunyai sebagian ciri bentuk lahan karst. Merokarst berkembang di batu gamping yang relatif tipis dan tidak murni, serta khususnya bila batu gamping diselingi oleh lapisan batuan napalan. Perkembangan secara vertikal tidak sedalam perkembangan holokarst dengan evolusi relief yang cepat.

- Karst Transisi berkembang di batuan karbonat relatif tebal yang memungkinkan perkembangan bentukan karst bawah tanah, akan tetapi batuan dasar yang impermeable tidak sedalam di holokarst, sehingga evolusi karst lebih cepat.

2. Klasifikasi Gvozdeckij (1965)

Gvozdeckij mengklasifikasi karst berdasarkan pengamatannya di Uni Soviet (sekarang Rusia). Klasifikasinya adalah sebagai berikut.

- Bare karst lebih kurang sama dengan karst Dinaric (holokarst). 
- Covered karst merupakan karst yang terbentuk bila batuan karbonat tertutup oleh lapisan aluvium, material fluvio-glacial, atau batuan lain seperti batu pasir.

- Soddy karst atau soil covered karst merupakan karst yang berkembang di batu gamping yang tertutup oleh tanah atau terra rosa yang berasal dari sisa pelarutan batu gamping.

- Buried karst merupakan karst yang telah tertutup oleh batuan lain, sehingga buktibukti karst hanya dapat dikenali dari data bor.

- Tropical karst of cone karst merupakan karst yang terbentuk di daerah tropis.

- Permafrost karst merupakan karst yang terbentuk di daerah bersalju.

3. Klasfikasi Sweeting (1972)

Klasifikasi Sweeting terutama didasarkan pada iklim. Berikut adalah klasifikasinya.

- True karst merupakan karst dengan perkembangan sempurna (holokarst). Karst yang sebenarnya harus merupakan karst dolin yang disebabkan oleh pelarutan secara vertikal. Semua karst yang bukan tipe dolin karst dikatakan sebagai deviant.

- Fluviokarst dibentuk oleh kombinasi antara proses fluvial dan proses pelarutan. Fluviokarst pada umumnya terjadi di daerah berbatuan gamping yang dilalui oleh sungai alogenik (sungai berhilir di daerah non-karst). Sebaran batu gamping baik secara lateral maupun vertikal jauh lebih kecil daripada true karst. Permukaan batu gamping di fluviokarst pada umumnya tertutup oleh tanah yang terbentuk oleh erosi dan sedimetasi proses fluvial.

- Glaciokarst merupakan karst yang terbentuk karena karstifikasi didominasi oleh proses glasiasi dan proses glasial di daerah yang berbatuan gamping. Glaciokarst terdapat di daerah berbatu gamping yang mengalami glasiasi atau pernah mengalami glasiasi. Glasiokarst dicirikan oleh kenampakankenampakan hasil penggogosan, erosi, dan sedimentasi glacier.
- Tropical karst secara lebih rinci dibedakan menjadi dua kelompok, yaitu: kegelkarst (sinoid karst, cone karst, atau karst a piton) dan turmkarst (karst tower, pinacle karst, atau karst a tourelles).

- Kegelkarst dicirikan oleh kumpulan bukit-bukit berbentuk kerucut yang sambung menyambung. Sela antar bukit kerucut membentuk cekungan dengan bentuk seperti bintang yang dikenal dengan kockpit. Kockpit seringkali membentuk pola kelurusan sebagai akibat kontrol kekar atau sesar. Depresi atau kockpit yang terkontrol kekar atau sesar ini oleh Lemann disebut gerichteterkarst (karst oriente).

- Turmkarst merupakan tipe karst kedua yang sering dijumpai di daerah tropis. Tipe karst ini dicirikan oleh bukit-bukit dengan lereng terjal, biasanya ditemukan dalam kelompok yang dipisahkan satu sama lain dengan sungai atau dataran aluvial.

- Karst menara dapat dibedakan menjadi dua kelompok. Pertama, bukit menara merupakan bukit sisa batu gamping yang terisolir di antara rataan batu gamping yang telah tertutup oleh endapan aluvium. Kedua, bukit menara merupakan bukit sisa dari batu gamping yang berada di dataran dengan batuan non karbonat.

4. Tipe karst lain

Selain klasifikasi di atas, literatur atau peneliti karst lain telah memberi nama tertentu untuk suatu kawasan karst. Penamaan yang digunakan hanya dimaksudkan untuk memberi nama tanpa bermaksud mengklasifikasi secara sistematis.

- Labyrint karst merupakan karst yang dicirikan oleh koridor-koridor atau ngarai memanjang yang terkontrol oleh kekar atau sesar. Morfologi karst tersusun oleh blokblok batu gamping yang dipisahkan satu sama lain oleh ngarai atau koridor karst.

- Karst Polygonal merupakan penamaan yang didasarkan dari sudut pandang morfometri 
dolin. Karst tipe ini dapat berupa karst kerucut maupun karst menara.

- Karst Fosil merupakan karst yang terbentuk pada masa geologi lampau dan saat ini proses karstifikasinya sudah berhenti (Sweeting, 1972). Dalam hal ini karstifikasi tidak berlangsung hingga saat ini karena perubahan iklim yang tidak lagi mendukung proses karstifikasi.

- Doline merupakan cekungan tertutup berbentuk bulat atau lonjong degan ukuran beberapa meter hingga lebih kurang satu kilometer (Ford dan Williams, 1992), sehingga Sweeting (1972) mengkategorikan doline dalam bentuk lahan karst berskala sedang. Kemiringan lereng miring hingga vertikal dengan kedalaman beberapa meter hingga ratusan meter. Doline merupakan bentuk lahan yang paling banyak dijumpai di kawasan karst.

- Polje merupakan merupakan bentuk lahan karst yang mempunyai elemen cekungan yang lebar, dasar yang rata, drainase karstik, bentuk memanjang yang sejajar dengan struktur lokal, dan dasar polje mempunyai lapisan batuan tersier.

5. Tipe karst di Indonesia

Sebagian besar kawasan karst di Indonesia tersusun oleh batuan karbonat, dan hampir tidak ada yang tersusun oleh batuan lain seperti gipsum, batu garam, maupun batuan evaporit. Hampir di setiap pulau di Indonesia memiliki batuan karbonat, tapi tidak semuanya terkarstifikasi menjadi kawasan karst. Berikut adalah klasifikasinya.

\section{- Tipe Gunung Sewu}

Tipe ini hadir berupa kawasan karst yang luas dan dicirikan bukit gamping berbentuk kerucut (konical) dan kubah yang jumlahnya ribuan. Selain itu didapati adanya lembah dolin dan polje diantara bukit-bukit tersebut. Di dalam dolin didapati adanya terrarosa yang menahan air sehingga tidak bocor ke dalam tanah. Sungai-sungai yang mengalir di bawah tanah akan bergabung membentuk sistem besar. Arah aliran sungai umumnya dikendalikan oleh struktur geologi. Tipe ini berkembang di sepanjang jalur pegunungan selatan dari Jawa Timur hingga Yogyakarta.

\section{- Tipe Gombong}

Bentang alam karst dicirikan oleh pembentukan cockpit, terutama yang dijumpai di daerah Selatan Gombong (daerah Karangbolong). Bentukan depresi yang ada umumnya dibatasi oleh lereng yang terjal dan kadang dijumpai bentukan seperti bintang. Karena batu gamping berada di atas lapisan batuan yang kedap air maka batas antara keduanya menjadi tempat keluarnya mata air.

\section{- Tipe Maros}

Tipe ini dicirikan oleh bukit-bukit yang berbentuk menara (tower karst atau mogote). Pembentukan bentang alam ini berkaitan dengan bidang retakan (kekar dan sesar) yang arahnya berkedudukan tegak atau hampir tegak. Tinggi menara antara 50-200 meter, berlereng terjal, dan datar pada bagian puncaknya. Di antara bukit-bukit tersebut terdapat lembah-lembah sempit, berdasar rata, dan berbentuk memanjang. Bentukan yang khas ini dijumpai di daerah Maros, Sulawesi Selatan.

- Tipe Wawolesea

Tipe ini dicirikan adanya lorong-lorong yang terisi oleh air panas dan di beberapa tempat terdapat jembatan alam (natural bridge). Tipe ini dicirikan terutama oleh kontrol hidrologi air panas sehingga terjadi proses pengendapan ulang larutan kalsit yang membentuk undak travertin yang beraneka ragam serta jarang dijumpai di tempat lain.

\section{- Tipe Semau}

Tipe ini merupakan tipe kawasan karst yang melibatkan batu gamping yang berumur muda (kala kwarter). Bentang alam yang dijumpai berupa surupan (sink) dan loronglorong gua yang pendek. Undak-undak pantai yang disusun oleh koral dapat mencapai tebal 25-100 meter dan mengalami pengangkatan $2,5 \mathrm{~cm} /$ tahun. Tipe Semau dijumpai pada Pulau Semau sebelah Barat Kupang, NTT. 


\section{- Tipe Nusa Penida}

Pulau Nusa Penida yang terletak di sebelah Selatan Pulau Bali memiliki kawasan karst yang tersusun atas batu gamping klastik dan nonklastik. Pada batu gamping klastik terdapat sisipan batuan berukuran halus dan kedap air. Adanya perulangan jenis batuan menyebakan terjadi keluaran air tanah yang bertingkat.

- Tipe Irian

Berdasarkan informasi yang ada, tipe karst di Irian dicirikan oleh adanya gua-gua panjang. Karst disusun oleh batu gamping klastik dan bioklastik, bahkan telah berubah menjadi metasedimen akibat kontak dengan intrusi batuan beku.

\section{METODOLOGI}

Dalam melakukan penelitian mengenai potensi karst di Kabupaten Pamekasan, ada beberapa langkah yang dilakukan guna mendapatkan peta zonasi karst dan peta potensi kawasan Pamekasan Utara. Langkah pertama yaitu pengumpulan data sekunder berupa peta geologi, peta rupa bumi (RBI), citra satelit, peta kawasan, peta guna lahan, Peta Penyusunan Rencana Tata Runag Wilayah (RTRW dan RDTR), data curah hujan (BMKG), UU dan perundangan, serta peraturan terkait pemanfaatan dan pelestarian kawasan karst. Pengumpulan data sekunder ini bertujuan sebagai data pendukung dan data awal sebelum survei. Selanjutnya adalah pengambilan data primer meliputi kegiatan survei di lapangan dan pemetaan pada kawasan karst.

Setelah mendapatkan data primer dan data sekunder yang berkaitan dengan pemetaan kawasan karst tahapan selanjutnya adalah pembuatan data base. Pembuatan data base dilakukan terhadap data primer hasil survei dan data sekunder yang nantinya akan diintegrasikan pada data base. Pembuatan data base bertujuan untuk mengelompokkan data-data yang dianggap penting untuk analisis dalam menentukan potensi kawasan di Pamekasan Utara sehingga mempercepat dan memaksimalkan proses analisis data nantinya. Setelah didapatkan data base berdasarkan data primer hasil survei dan data sekunder tahapan selanjutnya adalah analisis data dan sintesis pada kedua data tersebut. Pada tahapan ini akan dipetakan mengenai potensi dan zonasi kawasan karst, pemetaan ini berdasarkan survei kawasan karst yang diintegrasikan dengan data-data sekunder yang berkaitan dengan karst. Tahapan terakhir dari penelitian yaitu pembuatan peta zonasi dan potensi kawasan Pamekasan Utara. Pembuatan peta zonasi dan potensi kawasan Pamekasan Utara didasari pada peta kawasan, peta guna lahan, peta $\mathrm{RBI}$, dan peta geologi yang kemudian dibandingkan dengan data hasil survei di lapangan.

\section{HASIL DAN PEMBAHASAN}

Kondisi geomorfologi daerah didasarkan pada kelas kemiringan lerengnya. Klasifikasi kemiringan lereng ini berpedoman pada penyusunan rehabilitasi lahan dan konservasi tanah sebagai berikut.

Tabel 1. Tabel Kelas Kemiringan Lereng Dan Nilai Skor Kemiringan Lereng.

\begin{tabular}{|c|c|c|}
\hline KELAS & KEMIRINGAN (\%) & KLASIFIKASI \\
\hline I & $0-8$ & Datar \\
\hline II & $>8-15$ & Landai \\
\hline III & $>15-25$ & Agak Curam \\
\hline IV & $>25-45$ & Curam \\
\hline V & $>45$ & Sangat Curam \\
\hline
\end{tabular}

Sumber : Pedoman Penyusunan Pola Rehabilitasi Lahan dan Konservasi Tanah, 1986.

Untuk mengetahui kemiringan lereng dari daerah penelitian tadi, digunakan software ArcGIS untuk menentukan kemiringannya (slope) lalu dianalisis berdasarkan tabel di atas. Sebagai batasan untuk setiap daerah penelitian, dibuat lintasan yang mengarah Utara-Selatan dan Barat-Timur yaitu untuk daerah Pamekasan Utara. 
Lokasi penelitian 2

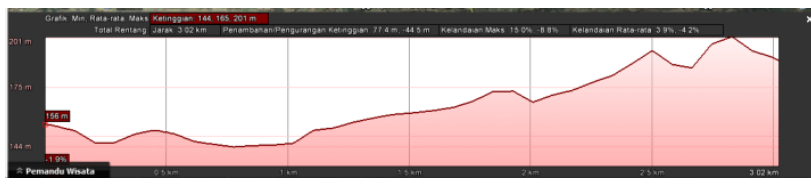

Gambar 1. Profil Kemiringan Lereng Lokasi Penelitian 2 yang Berarah Utara-Selatan.

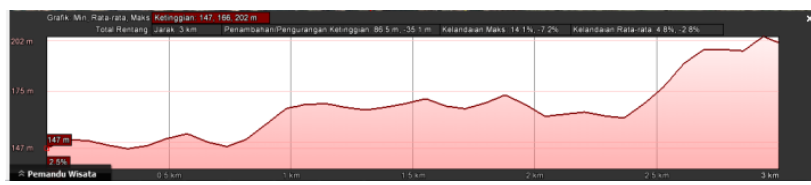

Gambar 1. Profil Kemiringan Lereng Lokasi Penelitian 2 yang Berarah Barat-Timur.

Pada lokasi penelitian 2 ini, dari Utara ke Selatan terlihat kelandaian maksimal sebesar 1,5\% hingga $8,8 \%$ dan kelandaian rata-rata sebesar 3,9\% hingga 4,2\% yang berarti morfologinya datar hingga landai. Sedangkan, dari Barat ke Timur terlihat kelandaian maksimal sebesar $14,1 \%$ hingga 7,2\% dan kelandaian rata-rata sebesar $4,8 \%$ hingga 2,8\% yang berarti morfologinya datar hingga landai.

\section{Lokasi penelitian 3}

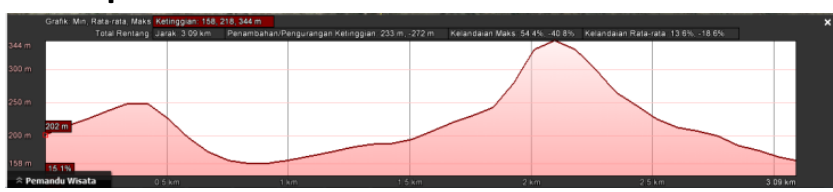

Gambar 2. Profil Kemiringan Lereng Lokasi Penelitian 3 yang Berarah Utara-Selatan.

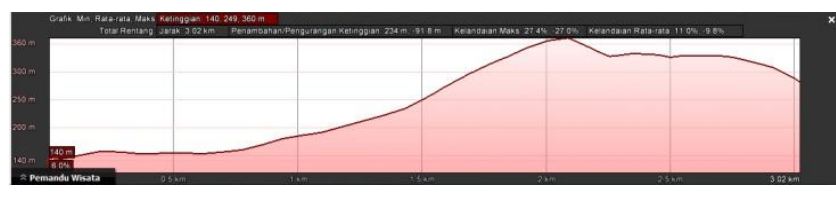

Gambar 3. Profil Kemiringan Lereng Lokasi Penelitian 3 yang Berarah Barat-Timur.

Pada lokasi penelitian 3 yaitu di Desa Waru Barat, dari Stara ke Selatan terlihat kelandaian maksimal sebesar 54,4\% hingga $-40,8 \%$ dan kelandaian rata-rata sebesar 13,6\% hingga 18,6\% yang berarti morfologinya datar hingga sangat curam. Sedangkan, dari Barat ke Timur terlihat kelandaian maksimal sebesar 27,4\% hingga 27,0\% dan kelandaian rata-rata sebesar $11,0 \%$ hingga $9,8 \%$ yang berarti morfologinya datar hingga curam.

\section{Lokasi penelitian 4 dan 5}

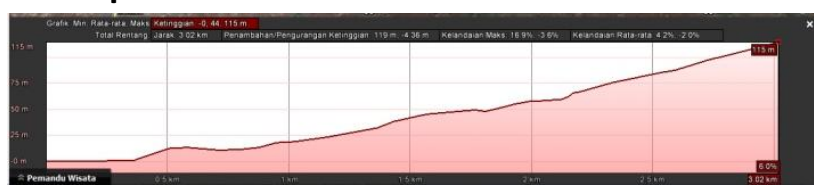

Gambar 4. Profil Kemiringan Lereng Lokasi Penelitian 4 dan 5 yang Berarah Utara-Selatan.

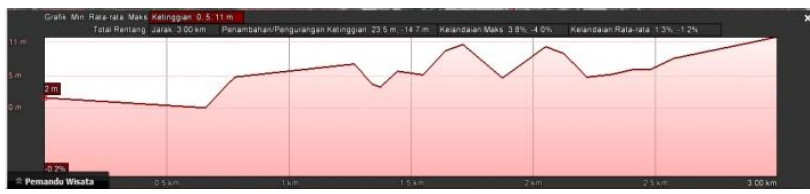

Gambar 5. Profil Kemiringan Lereng Lokasi Penelitian 4 dan 5 Yang Berarah Barat-Timur.

Karena pada lokasi penelitian 4 dan 5 samasama di Desa Kapong, maka batasannya digabung, dari Utara ke Selatan terlihat kelandaian maksimal sebesar $16,9 \%$ hingga 3,6\% dan kelandaian ratarata sebesar 4,2\% hingga 2,0\% yang berarti morfologinya datar hingga agak curam. Sedangkan, dari Barat ke Timur terlihat kelandaian maksimal sebesar 3,8\% hingga 4,0\% dan kelandaian rata-rata sebesar $1,3 \%$ hingga $1,2 \%$ yang berarti morfologinya datar.

\section{Lokasi penelitian 6 dan 7}

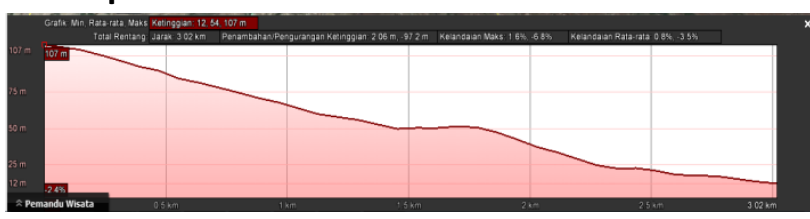

Gambar 6. Profil Kemiringan Lereng Lokasi Penelitian 6 dan 7 yang Berarah Utara-Selatan.

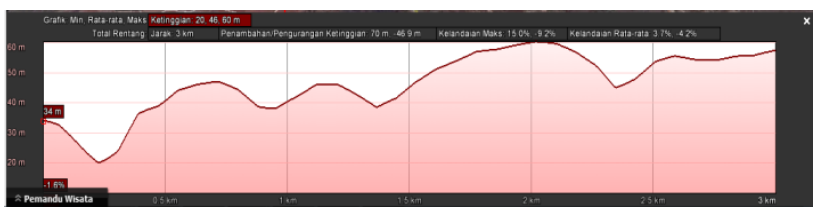

Gambar 7. Profil Kemiringan Lereng Lokasi Penelitian 6 dan7 yang Berarah Barat-Timur

Karena pada lokasi penelitian 6 dan 7 samasama di Desa Blaban, maka batasannya digabung, dari Utara ke Selatan terlihat kelandaian maksimal sebesar 1,6\% hingga 6,8\% dan kelandaian rata-rata sebesar $0,8 \%$ hingga $3,5 \%$ yang berarti morfologinya datar. Sedangkan, dari Barat ke Timur terlihat kelandaian maksimal sebesar 15\% hingga 
9,2\% dan kelandaian rata-rata sebesar 3,7\% hingga $4,2 \%$ yang berarti morfologinya datar hingga landai.

Fasies batuan sedimen yang terdapat di wilayah Kabupaten Pamekasan terdiri atas Holosen Alluvium, Pliosen Limestone Facies, Miosen Sendimentary Facies, dan Cleiston Clay Sedimentary. Di bawah ini disajikan data klasifikasi luas wilayah Kabupaten Pamekasan, berdasarkan struktur batuan atau geologinya.

Table 2. Geologi Daerah Penelitian.

\begin{tabular}{|c|c|c|c|c|}
\hline \multirow{2}{*}{$\begin{array}{l}\mathrm{N} \\
\mathrm{o}\end{array}$} & \multirow{2}{*}{$\begin{array}{c}\text { Umur } \\
\text { Pembentuk } \\
\text { an }\end{array}$} & \multirow{2}{*}{$\begin{array}{c}\text { Batuan } \\
\text { Pembentuk }\end{array}$} & \multicolumn{2}{|c|}{ Luas } \\
\hline & & & $\begin{array}{c}\text { Hektar } \\
\text { (Ha) }\end{array}$ & $\%$ \\
\hline 1. & Holosen & Alluvium & 17,689 & 22,33 \\
\hline 2. & Pliosen & $\begin{array}{l}\text { Limestone } \\
\text { Facies }\end{array}$ & 23,411 & 29,55 \\
\hline 3. & Miosen & $\begin{array}{c}\text { Sedimentar } \\
\text { y Facies }\end{array}$ & 33,768 & 42,62 \\
\hline 4. & Cleiston & $\begin{array}{c}\text { Clay } \\
\text { sedimentar } \\
\text { y }\end{array}$ & 4,362 & 5,50 \\
\hline \multicolumn{3}{|c|}{ Jumlah } & 79,230 & $\begin{array}{c}100,0 \\
0\end{array}$ \\
\hline
\end{tabular}

Dari data di atas, terlihat bahwa lapisan batuan sedimen mendominasi hampir separuh luas wilayah Kabupaten Pamekasan, ini menandakan bahwa sebagian besar lapisan tanah di Pamekasan telah mengalami erosi dan sedimentasi, dimana pada peristiwa erosi dan sedimentasi, biasanya disertai pembalikan horizon tanah. Kondisi struktur batuan induk Madura secara keseluruhan yang terbentuk oleh batuan gamping atau kapur.

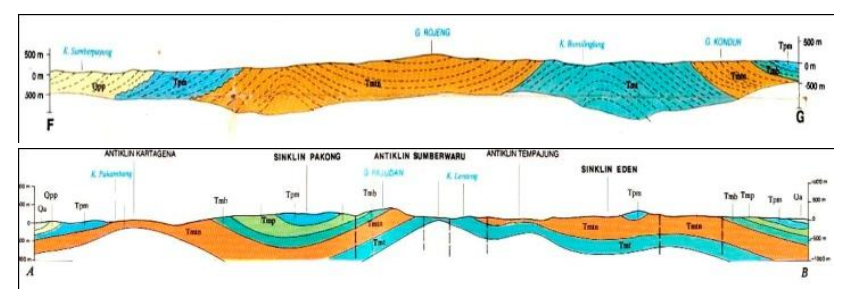

Gambar 8. Statigrafi dari Formasi di Kabupaten Pamekasan (Sumber: Peta Geologi Dari Pusat Penelitian dan Pengemmbangan Geologi, 1992)
Berdasarkan hasil survei yang dilakukan, diketahui bahwa kawasan karst berada di daerah sekitar Antiklin Tempajung dan Sinklin Eden di atas formasi Tmtn (Formasi Ngrayong). Berdasarkan data statigrafi dari peta geologi dapat dikatakan bahwa wilayah karst di Pamekasan Utara terbentuk akibat proses sedimentasi, dengan dominasi terbentuk pada perselingan batu pasir kuarsa dengan batu gamping arbitiod dan batu lempung.

Survei yang dilakukan di Pamekasan Selatan berada pada Tmtn (Formasi Ngrayong), dan ditemukan singkapan batu gamping dan pelapisan kasar antara lempung dan gamping. Survei di Pamekasan Tengah, khusus untuk Formasi Bulu ditemukan perselingan siltstone dan batu pasir halus, singkapan yang ada berupa lingkungan pengendapan daerah transisi dimana ditemukan batuan napal, fosil terumbu karang, lempung hitam, dan limonit. Survei di Pamekasan Utara berada pata Tmt (Formasi Madura), Tmtn (Formasi Ngrayong), dan Tpm (Formasi Pasean), ditemukan adanya karst, penemuan karst di formasi pasean (Tpm) yang tersingkap di permukaan, ditemukan juga kawasan karst yang berada di bawah permukaan yang berbentuk gua karst dengan terdapat stalaktit, stalakmit, dan spheleoterm.

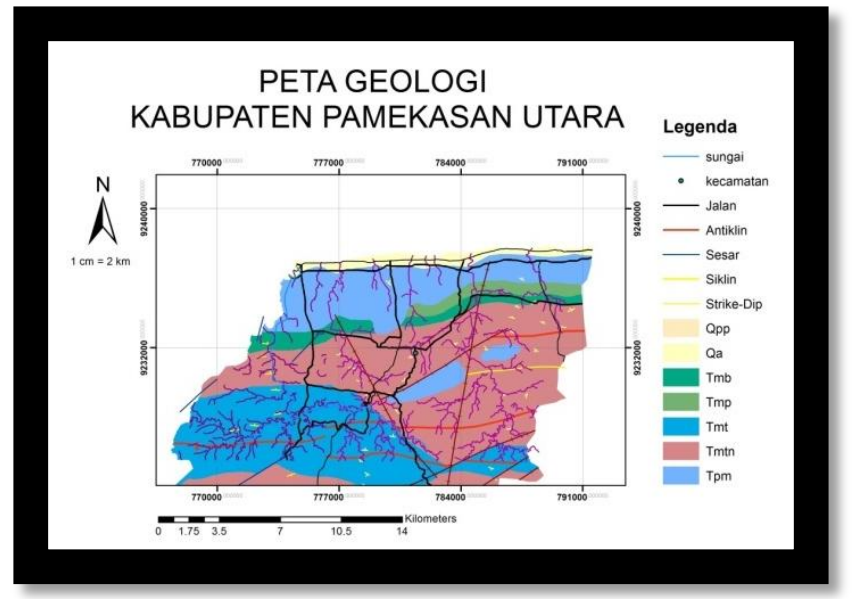

Gambar 9. Peta Geologi Kabupaten Pamekasan Utara. 
Karst yang ditemukan memiliki morfologi yang beraneka ragam, misalnya kerucut karst, gua, dan sungai bawah tanah. Gunung Waru sebagai salah satu potensi gua karst dengan dibuktikan adanya gua pada tengah gunung dan batu gamping berterumbu karang yang telah mengalami karstifikasi (diperlihatkan oleh Gambar 11), yang dapat merepresentasikan kondisi pada Gunung Waru bahwa daerah tersebut telah mengalami karstifikasi yang akan membentuk gua-gua karst.

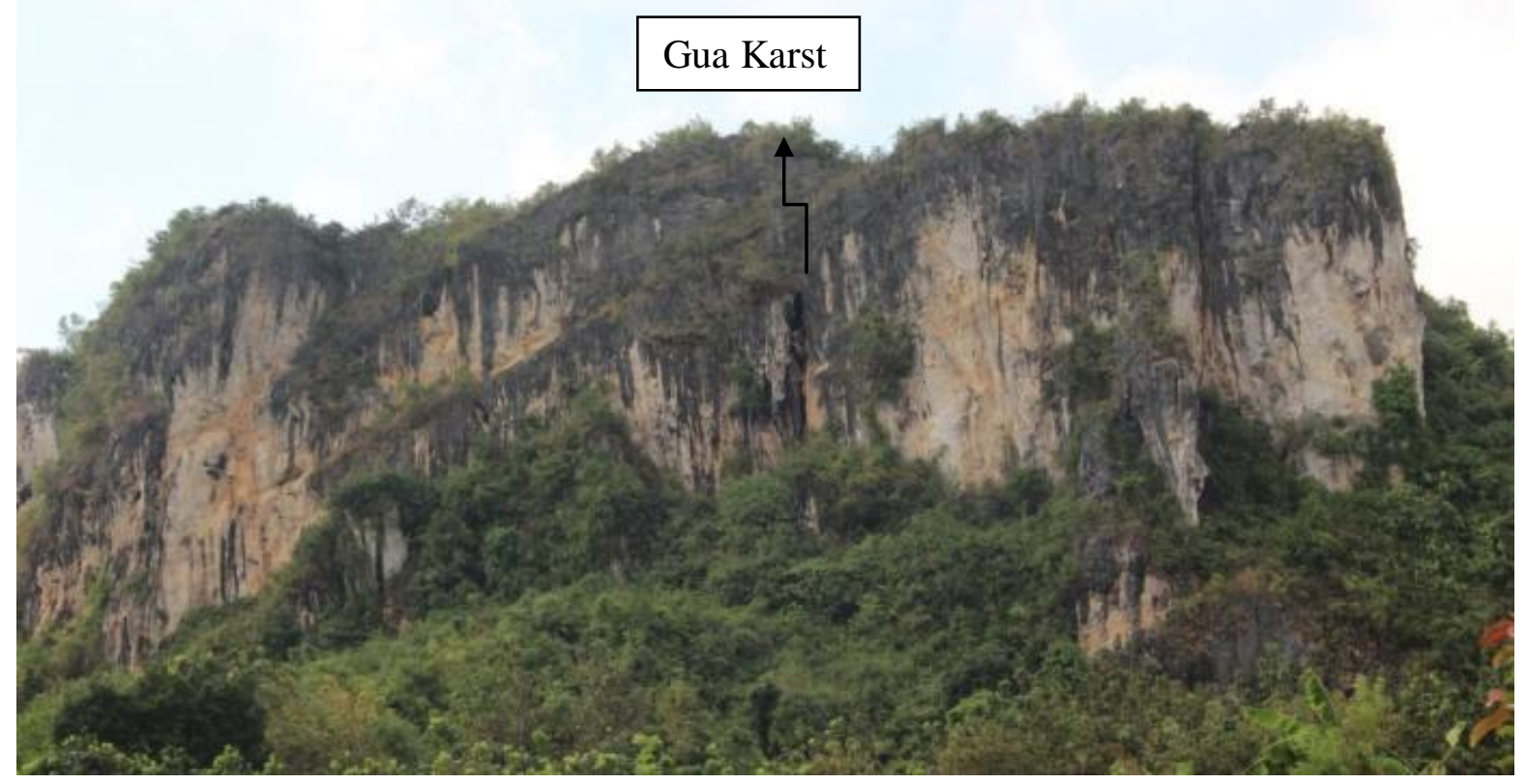

Gambar 10. Gunung Waru dengan Litologi Batu Gamping yang Disinyalir Terdapat Gua Karst.

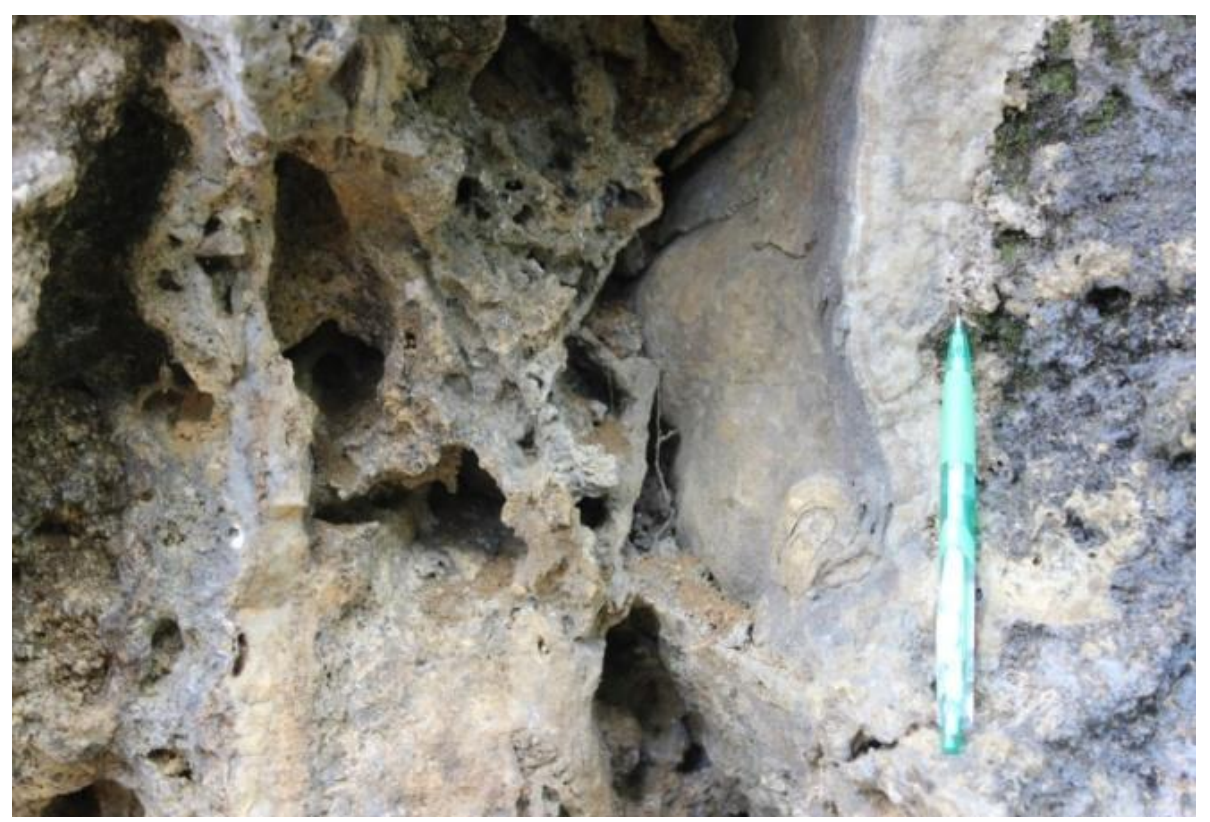

Gambar 11. Litologi Daerah Gunung Waru Dimana Terdapat Gejala Karstifikasi pada Batu Gamping Terumbu. 
Litologi yang sama dengan Gunung Waru juga ditemukan di Gunung Bongagung dan Gunung Paseset (diperlihatkan oleh Gambar 12).

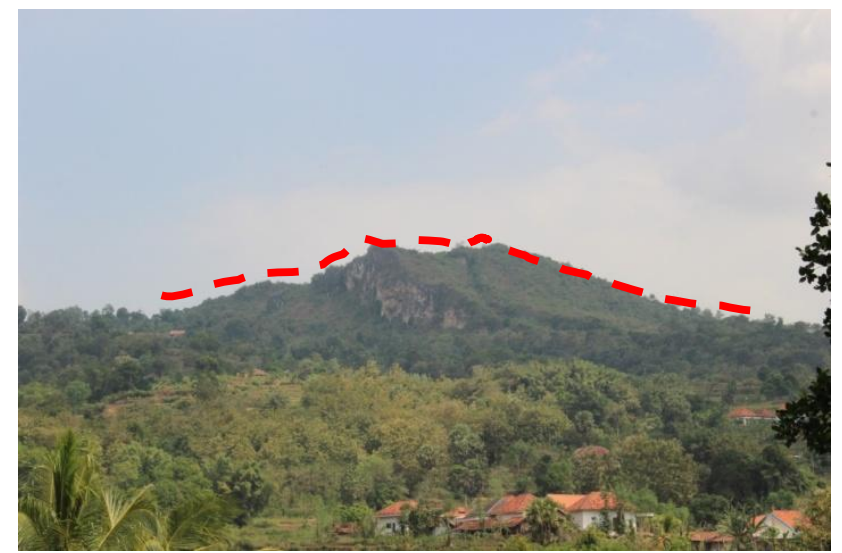

Gambar 12. Gunung Bongagung dan Gunung Paseset yang Memiliki Litologi yang Sama dengan Gunung Waru.

Di Kabupaten Pamekasan ditemukan pula kerucut karst (diperlihatkan oleh Gambar 13). Terdapatnya kerucut karst pada Formasi Bulu (Tbm), kerucut karst dapat dikenali dengan melihat bentuk morfologi perbukitan yang membentuk kerucut seperti pada Gambar 13.

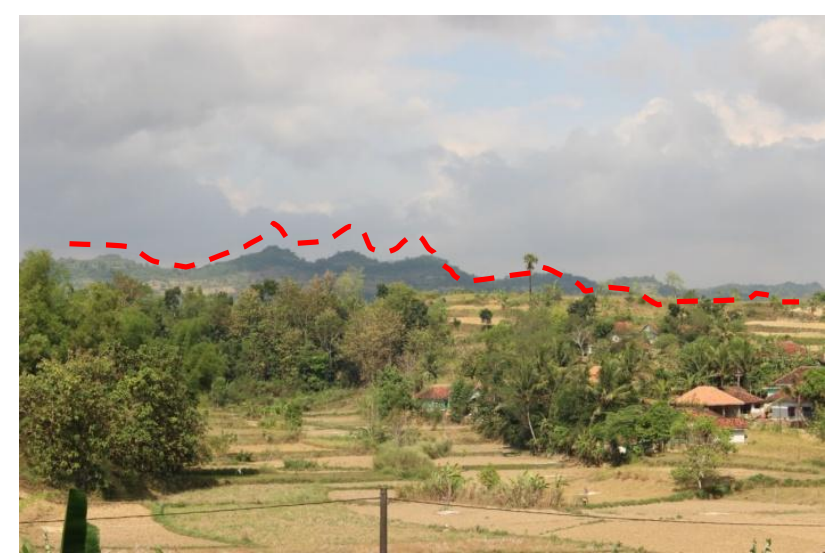

Gambar 13. Kerucut Karst, Berada di Tengah Kabupaten Pamekasan.

Kawasan karst memiliki banyak potensi sumber daya alam, di antaranya flora, fauna, dan sumber daya air. Flora ekosistem karst memiliki fungsi ekonomis maupun ekologis yang sangat tinggi, misalnya Manihot esculenta Crantz (singkong) sebagai tanaman pangan dan sayuran, Euphorbia milii (mahkota duri) sebagai tanaman hias, Hyptis capitata (srengenge) sebagai tanaman hias juga bahan pangan, Urena lobata L. sebagai tumbuhan obat, dll.

Fauna yang terdapat di daerah karst meliputi mamalia, burung, reptil, amfibi, ikan, moluska, serangga, arthropoda, dan invertebrata lain. Peran mereka di dalam ekosistem adalah sebagai; pemangsa dan pemarasit, penyerbuk bunga, pemencar biji, indikator hayati, perombak bahan organik, dan penyeimbang ekosistem. Misalnya, kelelawar sebagai pemakan serangga berperan sebagai pengendali hama pertanian, serta kupukupu dan kelelawar sebagai pembantu proses penyerbukan.

Kondisi permukaan wilayah bertopografi karst pada umumnya kering dan kritis. Namun demikian, di bagian bawah permukaan terdapat potensi sumber air yang sangat berlimpah. Sumber air Baron di karst Gunung Sewu - Yogyakarta adalah contoh melimpahnya air sungai bawah tanah daerah karst. Potensi yang terkandung pada sumber air tersebut mencapai 8000 liter/detik (Adji, 2006), sementara hingga saat ini yang termanfaatkan baru mencapai 15 liter/detik (Sunarto, 2002).

Sifat batuan karbonat ataupun dolomit yang menjadi penyusun utama bentang lahan karst adalah memiliki banyak rekahan, celah, dan rongga pada bagian permukaan. Bagian tersebut dinamakan dengan zona epikarst. Zona ini menjadi zona penangkap air yang jatuh ditempat tersebut. Celah, rekah, dan rongga tersebut akan terhubung dengan lorong-lorong konduit yang berada di zona vadose yang berada dibawah zona epikarst. Air yang ada di permukaan pada zona epikarst akan teresap ke lorong sungai bawah tanah melalui rekahan-rekahan tersebut menuju lorong-lorong sungai bawah tanah di zona vadose. Zona vadose merupakan bagian batuan karbonat yang tebal, dan tidak banyak memiliki rekah. Pada zona ini loronglorong konduit terbentuk. Lorong konduit ini dapat dilihat dalam bentuk gua atau pun lorong sungai bawah tanah.

Selain memiliki potensi sumber daya alam, karst juga memiliki potensi wisata. 
Juga bernilai estetika, keunikan, kelangkaan, dan tidak ada padanannya di tempat lain. Nilai tambah itu bermuatan sebagai aset dasar bidang industri pariwisata. Misalnya gua karst yang ada di Desa Blaban. Terdapat hal yang berbeda pada gua karst yang berada di Desa Blaban, Kecamatan Waru, Kabupaten Pamekasan. Dimana gua karst yang berada di sana memiliki bentuk dan struktur yang berbeda apabila dibandingkan dengan gua karst lain di Indonesia. Perbedaan ini terlihat dari fisik stalagmit, stalagtit, dan stalagnat yang ada di gua, salah satunya adalah warna putih yang masih bersih dan terdapat kristal (diperlihatkan oleh Gambar 14, bagian atas) hal ini memiliki daya pikat yang lebih bagi pengunjung gua karst di Desa Blaban, Kecamatan Waru.

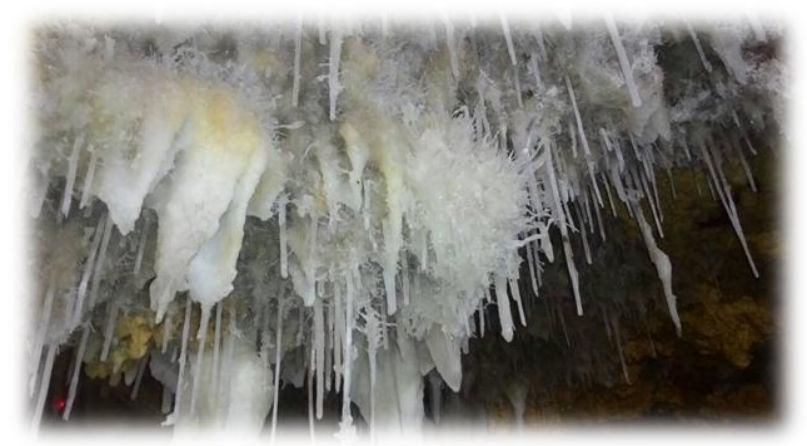

Gambar 14. Kenampakan Stalaktit di Gua Karst, Desa Blaban,Kecamatan Waru.

Dengan ditemukannya gua karst yang cukup besar di Desa Blaban, Kecamatan Waru, Kabupaten Pamekasan dapat dijadikan salah satu lokasi pariwisata gua karst di Kabupaten Pamekasan. Dengan adanya gua karst ini dapat menarik wisatawan untuk berkunjung ke Kabupaten Pamekasan, tentunya terlebih dahulu harus ada pengelolaan yang jelas terhadap gua karst ini. Realitas di lapangan yang terkait dengan industri pariwisata, keberadaan gua pada umumnya belum bisa dinikmati maksimal. Wisatawan lazimnya hanya masuk gua melihat stalagtit dan stalagmit. Padahal, paket belajar menelusuri gua cukup menarik, bermuatan petualangan. Memang perlu guide yang berkualitas untuk memandu wisatawan, selain perlu ada literatur dan bimbingan penelusuran gua. Tentu perlu peralatan tertentu atau khusus yang mendukung paket wisata tersebut.

Dengan manajemen yang baik pada gua karst yang akan dijadikan lokasi pariwisata di Kabupaten Pamekasan dihadapkan akan menjadi salah satu destinasi wisata terbaik di Indonesia. Selain manajemen yang baik, diperlukan juga pencarian gua-gua karst lainnya karena Formasi Pasean yang berada di Pamekasan Utara masih sangat luas untuk dicari potensinya, sehingga dapat dijadikan pusat wisata karst di Indonesia.

Berdasarkan kenampakan morfologi karstnya, Kawasan karst di Pamekasan Utara tergolong ke dalam "merokarst". Merokarst merupakan karst dengan perkembangan tidak sempurna atau parsial dengan hanya mempunyai sebagian ciri bentuk lahan karst. Merokarst berkembang di batu gamping yang relatif tipis dan tidak murni, serta khususnya bila batu gamping diselingi oleh lapisan batuan napalan. Persebaran daerah pertambangan di Kabupaten Pamekasan berada di bagian tengah dan Utara Kabupaten Pamekasan. Dimana kawasan pertambangan terdiri dari pertambangan fosfat, lempung, pasir kuarsa, dan batu gamping.

Pembuatan peta potensi sumber daya alam untuk pertambangan dan zonasi daerah karst bertujuan untuk penentuan zona yang tidak boleh ditambang walaupun memiliki potensi untuk pertambangan. Berdasarkan pada bab sebelumnya, dimana karst memiliki potensi yang besar baik sumber daya alam dan pariwisata maka seharusnya daerah karst dijadikan daerah konservasi yang tidak boleh terjadi eksploitasi untuk pertambangan. Apabila ditinjau dari dampak pertambangan itu sendiri akan memberikan manfaat yang lebih sedikit dibandingkan dengan menjadikan daerah konservasi pada kawasan karst. Pembuatan peta zona penambangan yang berbasis pada konservasi kawasan karst diperlihatkan oleh gambar berikut. 


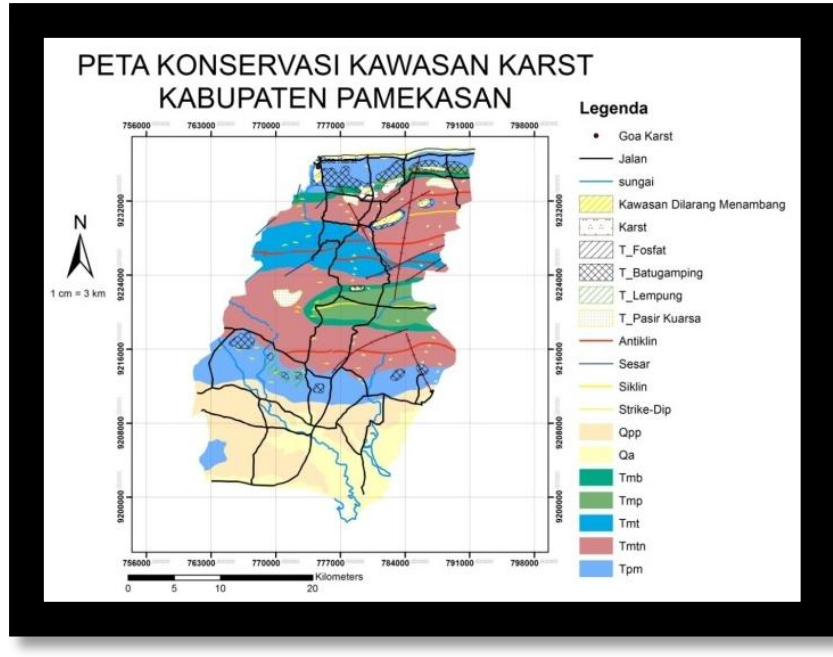

Gambar 15. Peta Zona Konservasi Karst.

\section{PENUTUP}

\section{Simpulan}

- Kawasan karst di Pamekasan Utara tergolong ke dalam merokarst, dimana proses karstifikasi berlangsung secara parsial sehingga hanya sebagian wilayah yang memiliki ciri bentuk lahan karst. Perkembangan secara vertikal tidak sedalam perkembangan holokarst dengan evolusi relief yang cepat. Zonasi kawasan karst tersebar di wilayah Pamekasan bagian utara dan sebagian kecil di bagian tengah.

- Potensi kawasan karst di wilayah Pamekasan Utara terbagi menjadi dua yaitu potensi karst sebagai sumber daya alam dan potensi pariwisata. Potensi sumber daya alam meliputi sumber air bersih, flora, dan fauna di kawasan karst. Sedangkan potensi pariwisata salah satunya terdapat pada gua karst yang berada di Desa Blaban, Kecamatan Waru.

- Pemanfaatan ruang kawasan karst dikelompokkan menjadi kawasan lindung dan kawasan budidaya. Untuk kawasan lindung karst di Pamekasan Utara termasuk kedalam kawasan resapan air dan penyimpan air bawah tanah. Sedangkan gua karst yang berada di Desa Blaban, Kecamatan Waru dapat dimasukkan kedalam kawasan wisata.

\section{Saran}

Berdasarkan Permen ESDM yang telah disebutkan di atas serta melihat potensi kawasan karst maka akan lebih bermanfaat apabila kawasan karst dilestarikan dari pada dijadikan daerah tambang. Pemanfaatan ruang kawasan karst didasarkan pada aspek geologi dan lingkungan dapat dikelompokkan menjadi kawasan lindung dan kawasan budidaya. Kawasan lindung karst dari aspek geologi dan lingkungan dapat dikelompokkan menjadi kawasan resapan air dan penyimpan air bawah tanah serta kawasan perlindungan setempat sempadan-sempadan gua, luweng, dan mata air. Untuk daerah Pamekasan Utara kawasan karst dapat termasuk kedalam kawasan resapan air dan penyimpan air bawah tanah. Kawasan lindung ini termasuk kawasan karst kelas 1, sehingga peruntukkanya tidak boleh ada kegiatan penambangan. Peruntukan kawasan ini sebagai kawasan resapan air

\section{DAFTAR PUSTAKA}

Adji, T. N., Sudarmadji, Woro, S., Hendrayana, H., Hariadi, B., 2006. The Distribution of Flood Hydrograph Recession Constant of Bribin River for Gunungsewu Karst Aquifer Characterization. Gunungsewu-Indonesian Cave and Karst Journal, Vol. 2. No. 2.

Ford, D. and Williams, P., 1992. Karst Geomorphology and Hydrology. Chapman and Hall, London.

Pedoman Penyusunan Pola Rehabilitasi Lahan dan Konservasi Tanah, 1986.

Peta Geologi dari Pusat Penelitian dan Pengemmbangan Geologi, 1992.

Sweeting, M.M., 1972. Karst Landforms. Macmillan: London. 